\title{
Azaspiracid variability of Azadinium poporum (Dinophyceae) from the China Sea
}

\author{
Bernd Krock $^{\mathrm{a}, *}$, Urban Tillmann ${ }^{\mathrm{a}}$, Matthias Witt ${ }^{\mathrm{b}}$, Haifeng $\mathrm{Gu}^{\mathrm{c}}$ \\ ${ }^{a}$ Alfred Wegener Institut Helmholtz-Zentrum für Polar- und Meeresforschung, Chemische Ökologie, Am Handelshafen 12, 27570 Bremerhaven, Germany \\ ${ }^{\mathrm{b}}$ BrukerDaltonik GmbH, Fahrenheitstr. 4, 28359 Bremen, Germany \\ ${ }^{\mathrm{c}}$ Third Institute of Oceanography, SOA, Xiamen 361005, PR China
}

\section{A R T I C L E IN F O}

\section{Article history:}

Received 9 October 2013

Received in revised form 11 April 2014

Accepted 11 April 2014

Available online

\section{Keywords:}

Azadinium poporum

Chinese coastal waters

Azaspiracid shellfish poisoning (AZP)

LC-MS/MS

Toxin profiles

AZA-40

AZA-41

\begin{abstract}
A B S T R A C T
Azadinium poporum is a small dinoflagellate from the family Amphidomataceae which is known for the potential production of azaspiracids (AZAs) causative of azaspiracid shellfish poisoning (AZP). A. poporum has been recorded from European and western Pacific waters. Here we report on the high variability of toxin profiles within this species in Chinese coastal waters. Out of 16 analyzed strains of $A$. poporum from different geographic locations along the Chinese coastline, three strains proved not to contain AZAs, whereas 13 strains contained different combinations of AZA-2, AZA-11, AZA-36, a yet unknown isomer of AZA-1 (named AZA-40) and new AZA with yet unreported molecular mass of $853 \mathrm{Da}$ (named AZA-41). The new AZA-40, other than AZA-1 itself, belongs to the recently discovered "348-type" group, which in tandem mass spectrometry displays a group 4 fragment with $m / z 348$ instead of the group 4 fragment of the classic AZAs with $m / z 362$, indicating a shift of a methyl group from the $C_{24}-C_{40}$ part of the molecule (rings $F-I$ ) to the $C_{2}-C_{9}$ part (carboxylic side chain and ring $A$ ). AZA-41 apparently is a dehydro variant of AZA-2. In addition, a previously reported AZA with a molecular mass 871 DA could be unambiguously assigned to AZA-11, which is known to be a shellfish metabolite of AZA-2. This is the first report of AZA-11 being also de novo synthetized by dinoflagellates.
\end{abstract}

() 2014 Elsevier B.V. All rights reserved.

\section{Introduction}

Among the known marine shellfish poisoning syndromes, azaspiracid shellfish poisoning (AZP) is the most recent one, which was observed for the first time in the Netherlands in 1995. Contaminated mussels cultivated in Ireland were consumed and intoxicated at least eight people (McMahon and Silke, 1996). Three years later the implicated toxin was identified, isolated, structurally defined and named azaspiracid (now called azaspiracid-1 (AZA-1) (Satake et al., 1998). In the following years other variants of AZA-1 were found and isolated from shellfish (Ofuji et al., 1999; James et al., 2003). As a result, the European Union has set a regulatory limit for maximum levels of AZAs in shellfish $\left(160 \mu \mathrm{g} \mathrm{kg}^{-1}\right)$. Due to their structural characteristics AZAs were early suspected to be of dinoflagellate origin, however, the AZAproducing organism remained unknown until the isolation of Azadinium spinosum from the North Sea in 2007 (Krock et al., 2009). Species of the genus Azadinium have so far been reported from the North Sea (Tillmann et al., 2009, 2010, 2011), the French and Irish

\footnotetext{
* Corresponding author. Tel.: +49 4714831 2055; fax: +49 47148312115 . E-mail address: bernd.krock@awi.de (B. Krock).
}

coast of the eastern Atlantic (Nézan et al., 2012; Salas et al., 2011), the Mediterranean Sea (Percopo et al., 2013), the Argentinean coast (Akselman and Negri, 2012), the Korean coast (Potvin et al., 2012) and the Chinese coast (Gu et al., 2013). Nevertheless, the presence of AZAs appeared to be distributed much more widely, reported in Northern Africa, northern Europe, Chile, USA and China (Braña Magdalena et al., 2003; James et al., 2002; Klontz et al., 2009; López-Rivera et al., 2010; Taleb et al., 2006; Yao et al., 2010). The discrepancy between the distribution of Azadinium and AZAs suggest that $A$. spinosum might have a wider distribution, or other Azadinium species could produce AZAs. Initially, A. spinosum was the only species for which AZAs were reported. For A. spinosum strain 3D9, the toxin profile consisted of AZA-1, AZA-2 and an isomer of AZA-2 (Krock et al., 2009), which was later identified as AZA-1 methyl ester and found to be an extraction artifact (Jauffrais et al., 2012). AZA-1 and -2 production was subsequently confirmed for A. spinosum strains from Denmark (Tillmann et al., 2011) and Ireland (Salas et al., 2011), indicating that production and profile of known AZAs is a stable characteristic of the species A. spinosum. Other related species/strains of Amphidomataceae have been reported not to contain any of the known azaspiracids. However, AZA production within Amphidomataceae probably is much more complex and diverse; recent evidence indicates the presence of 
new AZAs with a modified substitution pattern in Azadinium poporum and Amphidoma languida (Krock et al., 2012). North Sea strains and the Korean isolate of $A$. poporum were found to produce AZAs with a characteristic $m / z$ 348-fragment, however, in two different variants with different masses in the North Sea strains and the Korean strain, respectively (Krock et al., 2012). Until recently AZP appeared to be a merely European problem, but the recent findings of Azadinium spp. and AZAs at different locations of the Asian Pacific (Gu et al., 2013; Potvin et al., 2012) give increasing evidence AZP may pose a potential seafood safety risk in this to date unaffected world region.

The aim of this work was to further investigate the occurrence and variability of AZAs and the distribution of the producing organisms in Chinese coastal waters.

\section{Materials and methods}

\subsection{Sample collection and treatment}

Sediment samples were collected along the coast of China using a grab sampler (geographical coordinates and sample dates were provided in Table 1). The sediment samples were stored in the dark at $4{ }^{\circ} \mathrm{C}$ until further treatment. Approximately, $2 \mathrm{~g}$ of wet sediment were mixed with $20 \mathrm{~mL}$ of filtered seawater and sonicated for $2 \mathrm{~min}(100 \mathrm{~W})$ to dislodge detrital particles. The watery slurry was incubated directly in series of small containers in $\mathrm{f} / 2$-Si medium (Guillard and Ryther, 1962) at $20{ }^{\circ} \mathrm{C}, 90 \mu \mathrm{E} \mathrm{m}^{-2} \mathrm{~s}^{-1}$ under a $12-\mathrm{h}$ light:12-h dark cycle (hereafter called "standard culture conditions"). Azadinium cells are characterized by swimming at low speed, interrupted by short, high-speed 'jumps' in various directions (Tillmann et al., 2009). Cells exhibiting such a characteristic swimming behavior were isolated by means of drawn-out Pasteur pipettes and established into clonal cultures. Only one strain was established from one container to guarantee they represent true clonal strains. 16 strains were established this way and maintained under standard culture conditions.

\subsection{PCR amplifications and sequencing}

Total algal DNA was extracted from $10 \mathrm{~mL}$ of exponentially growing Azadinium cultures using a plant DNA extraction kit (Sangon, Shanghai, China) according to the manufacturer's protocol. The total ITS1-5.8S-ITS2 was amplified using ITSA and ITSB primers (Adachi et al., 1996).

The PCR protocol was as follows: initial denaturation for $3.5 \mathrm{~min}$ at $94^{\circ} \mathrm{C}$, followed by 35 cycles of $50 \mathrm{~s}$ denaturation at $94{ }^{\circ} \mathrm{C}, 50 \mathrm{~s}$ annealing at $45^{\circ} \mathrm{C}$, and $80 \mathrm{~s}$ extension at $72{ }^{\circ} \mathrm{C}$, plus a final extension of $10 \mathrm{~min}$ at $72{ }^{\circ} \mathrm{C}$. PCR products were sequenced directly in both directions using the ABI Big-Dye dye-terminator technique (Applied Biosystems, Foster City, CA, USA), according to the manufacturer's recommendations. The BLAST programs are used for searching DNA databases for sequence similarities (Altschul et al., 1997).

\subsection{Chemical analysis of azaspiracids}

For AZA analysis, cultures of $A$. poporum were grown in $200 \mathrm{~mL}$ Erlenmeyer flasks under standard culture conditions. Around $10^{7}$ cells were collected by centrifugation at the exponential phase. Cell pellets were extracted with $400 \mu \mathrm{L}$ acetone by reciprocal shaking at $6.5 \mathrm{~m} \mathrm{~s}^{-1}$ with $0.9 \mathrm{~g}$ lysing matrix D (Thermo Savant, Illkirch, France) in a Bio101 FastPrep instrument (Thermo Savant, Illkirch, France) for $45 \mathrm{~s}$. Extracts were then centrifuged (Eppendorf $5415 \mathrm{R}$, Hamburg, Germany) at $16,100 \times g$ at $4{ }^{\circ} \mathrm{C}$ for $15 \mathrm{~min}$. Each supernatant was transferred to a $0.45-\mu \mathrm{m}$ pore-size spin-filter (Millipore Ultrafree, Eschborn, Germany) and centrifuged for $30 \mathrm{~s}$ at $800 \times \mathrm{g}$, and the resulting filtrate being transferred into an LC autosampler vial for LC-MS/MS analysis.

\subsubsection{Single reaction monitoring (SRM) measurements}

Water was deionized and purified (Milli-Q, Millipore, Eschborn, Germany) to $18 \mathrm{M} \Omega \mathrm{cm}^{-1}$ or better quality. Formic acid (90\%, p.a.), acetic acid (p.a.) and ammonium formate (p.a.) were purchased from Merck (Darmstadt, Germany). The solvents, methanol and acetonitrile, were high performance liquid chromatography (HPLC) grade (Merck, Darmstadt, Germany).

Mass spectral experiments were performed to survey for a wide array of AZAs. The analytical system consisted of an ABI-SCIEX4000 Q Trap, triple quadrupole mass spectrometer equipped with a TurboSpray ${ }^{\circledR}$ interface coupled to an Agilent model 1100 LC. The LC equipment included a solvent reservoir, in-line degasser (G1379A), binary pump (G1311A), refrigerated autosampler (G1329A/G1330B), and temperature-controlled column oven (G1316A).

Table 1

Strains of Azadinium poporum examined in the present study, including their origin, collection dates, ribotypes, AZA-cell quotas [fg cell-1 ] and toxin profiles.

\begin{tabular}{|c|c|c|c|c|c|c|c|c|c|c|c|c|c|}
\hline Strain & Origin & Latitude & Longitude & $\begin{array}{l}\text { Collection } \\
\text { date }\end{array}$ & $\begin{array}{l}\text { Ribo- } \\
\text { type }\end{array}$ & AZA-40 & AZA-41 & AZA-2 & AZA-36 & AZA-11 & AZA-profile & $\begin{array}{l}\text { Profile } \\
\text { type }\end{array}$ & Source \\
\hline AZBH 01 & South China Sea & $21^{\circ} 23^{\prime} 17^{\prime \prime}$ & $109^{\circ} 23^{\prime} 17^{\prime \prime}$ & 24.05 .2010 & B & 0.9 & - & - & - & - & AZA-40 & $\mathrm{D}$ & This study \\
\hline AZBH 03 & South China Sea & $21^{\circ} 23^{\prime} 17^{\prime \prime}$ & $109^{\circ} 07^{\prime} 16^{\prime \prime}$ & 24.05 .2010 & B & 0.5 & - & - & - & - & AZA-40 & $\mathrm{D}$ & This study \\
\hline AZCH 01 & Yellow Sea & $39^{\circ} 14^{\prime} 59^{\prime \prime}$ & $122^{\circ} 36^{\prime} 05^{\prime \prime}$ & 02.05 .2011 & $\mathrm{C}$ & - & - & - & - & - & no AZAs & A & This study \\
\hline AZCH 10 & Yellow Sea & $39^{\circ} 14^{\prime} 59^{\prime \prime}$ & $122^{\circ} 36^{\prime} 05^{\prime \prime}$ & 02.05 .2011 & B & - & - & - & 0.7 & 0.2 & AZA-11, -36 & $\mathrm{~F}$ & This study \\
\hline AZDH 38 & East China Sea & $30^{\circ} 00^{\prime} 00^{\prime \prime}$ & $122^{\circ} 44^{\prime} 48^{\prime \prime}$ & 19.04.2011 & B & - & 0.9 & - & - & - & AZA-41 & E & This study \\
\hline AZDH 39 & East China Sea & $30^{\circ} 00^{\prime} 00^{\prime \prime}$ & $122^{\circ} 44^{\prime} 48^{\prime \prime}$ & 19.04.2011 & $\mathrm{C}$ & - & - & 3.9 & 0.6 & - & AZA-2, -36 & $\mathrm{C}$ & This study \\
\hline AZDH 41 & East China Sea & $30^{\circ} 00^{\prime} 00^{\prime \prime}$ & $122^{\circ} 44^{\prime} 48^{\prime \prime}$ & 19.04.2911 & B & - & - & - & - & 3.0 & ATA-11 & B & This study \\
\hline AZDH 43 & East China Sea & $30^{\circ} 00^{\prime} 00^{\prime \prime}$ & $122^{\circ} 44^{\prime} 48^{\prime \prime}$ & 19.04.2011 & B & - & - & - & - & 0.8 & AZA-11 & B & This study \\
\hline AZDH 51 & East China Sea & $30^{\circ} 00^{\prime} 00^{\prime \prime}$ & $122^{\circ} 44^{\prime} 48^{\prime \prime}$ & 19.04.2011 & $\mathrm{C}$ & - & - & - & - & - & no AZAs & A & This study \\
\hline AZDH 55 & East China Sea & $30^{\circ} 00^{\prime} 00^{\prime \prime}$ & $122^{\circ} 44^{\prime} 48^{\prime \prime}$ & 19.04.2011 & B & - & - & - & - & 1.6 & AZA-11 & B & This study \\
\hline AZDH 56 & East China Sea & $30^{\circ} 00^{\prime} 00^{\prime \prime}$ & $122^{\circ} 44^{\prime} 48^{\prime \prime}$ & 19.04 .2011 & $\mathrm{C}$ & - & - & 1.8 & 0.3 & - & AZA-2, -36 & C & This study \\
\hline AZDY 06 & South China Sea & $22^{\circ} 36^{\prime} 08^{\prime \prime}$ & $114^{\circ} 37^{\prime} 21^{\prime \prime}$ & 05.06.2010 & B & - & - & 7.6 & 1.2 & - & AZA-2, -36 & $\mathrm{C}$ & This study \\
\hline AZFC 21 & South China Sea & $21^{\circ} 29^{\prime} 58^{\prime \prime}$ & $108^{\circ} 13^{\prime} 53^{\prime \prime}$ & 28.04 .2011 & $\mathrm{C}$ & 0.2 & - & - & - & 0.5 & AZA-11, -40 & $\mathrm{H}$ & This study \\
\hline AZFC 22 & South China Sea & $21^{\circ} 29^{\prime} 58^{\prime \prime}$ & $108^{\circ} 13^{\prime} 53^{\prime \prime}$ & 28.04 .2011 & $\mathrm{C}$ & - & - & 4.4 & - & - & AZA-2 & G & This study \\
\hline AZLY 01 & Yellow Sea & $34^{\circ} 47^{\prime} 49^{\prime \prime}$ & $119^{\circ} 31^{\prime} 08^{\prime \prime}$ & 09.05.2011 & B & - & - & - & 0.4 & 1.0 & AZA-11, -36 & $\mathrm{F}$ & This study \\
\hline AZLY 02 & Yellow Sea & $34^{\circ} 47^{\prime} 49^{\prime \prime}$ & $119^{\circ} 31^{\prime} 08^{\prime \prime}$ & 09.05 .2011 & B & - & - & - & - & - & no AZAs & A & This study \\
\hline G 25 & Bohai Sea & $38^{\circ} 54^{\prime} 60^{\prime \prime}$ & $117^{\circ} 53^{\prime} 00^{\prime \prime}$ & 14.08.2007 & B & - & - & - & 1.4 & - & AZA-36 & $\mathrm{C}$ & Gu et al. (2013) \\
\hline G 42 & East China Sea & $30^{\circ} 00^{\prime} 00^{\prime \prime}$ & $122^{\circ} 44^{\prime} 48^{\prime \prime}$ & 19.04.2011 & $\mathrm{C}$ & - & - & 6 & - & - & AZA-2 & G & Gu et al. (2013) \\
\hline G 60 & East China Sea & $30^{\circ} 00^{\prime} 00^{\prime \prime}$ & $122^{\circ} 44^{\prime} 48^{\prime \prime}$ & 19.04.2011 & B & - & - & - & - & - & no AZAs & A & Gu et al. (2013) \\
\hline G 64 & East China Sea & $30^{\circ} 00^{\prime} 00^{\prime \prime}$ & $122^{\circ} 44^{\prime} 48^{\prime \prime}$ & 19.04.2011 & $\mathrm{C}$ & - & - & $8-23$ & - & - & AZA-2 & G & Gu et al. (2013) \\
\hline G 66 & East China Sea & $30^{\circ} 00^{\prime} 00^{\prime \prime}$ & $122^{\circ} 44^{\prime} 48^{\prime \prime}$ & 19.04.2011 & B & - & - & - & - & 1.5 & AZA-11 & G & Gu et al. (2013) \\
\hline G 68 & South China Sea & $21^{\circ} 29^{\prime} 58^{\prime \prime}$ & $108^{\circ} 13^{\prime} 53^{\prime \prime}$ & 28.04 .2011 & B & - & - & $2-5$ & - & - & AZA-2 & G & Gu et al. (2013) \\
\hline
\end{tabular}


Separation of AZAs ( $5 \mu \mathrm{L}$ sample injection volume) was performed by reverse-phase chromatography on a $C 8$ phase. The analytical column $(50 \times 2 \mathrm{~mm})$ was packed with $3 \mu \mathrm{m}$ Hypersil BDS $120 \AA$ (Phenomenex, Aschaffenburg, Germany) and maintained at $20^{\circ} \mathrm{C}$. The flow rate was $0.2 \mathrm{~mL} \mathrm{~min}^{-1}$ and gradient elution was performed with two eluants, where eluant $A$ was water and $B$ was acetonitrile/water $(95: 5, \mathrm{v} / \mathrm{v})$, both containing $2.0 \mathrm{mM}$ ammonium formate and $50 \mathrm{mM}$ formic acid. Initial conditions were 8 min column equilibration with $30 \%$ B, followed by a linear gradient to $100 \% \mathrm{~B}$ in $8 \mathrm{~min}$ and isocratic elution until $18 \mathrm{~min}$ with $100 \%$ B then returning to initial conditions until $21 \mathrm{~min}$ (total run time: $29 \mathrm{~min})$.

AZA profiles were determined in one period (0-18 min) with curtain gas: $10 \mathrm{psi}, \mathrm{CAD}$ : medium, ion spray voltage: $5500 \mathrm{~V}$, temperature: ambient, nebulizer gas: $10 \mathrm{psi}$, auxiliary gas: off, interface heater: on, declustering potential: $100 \mathrm{~V}$, entrance potential: $10 \mathrm{~V}$, exit potential: $30 \mathrm{~V}$ ). SRM experiments were carried out in positive ion mode by selecting the transitions shown in Table 2. AZAs were calibrated against an external standard solution of AZA-1 (certified reference material (CRM) programme of the IMB-NRC, Halifax, Canada) and expressed as AZA-1 equivalents. A solution containing AZA-11, previously isolated from shellfish and purified by the Marine Institute, Oranmore, Galway, Ireland was kindly donated by Jane Kilcoyne.

\subsubsection{Precursor ion experiments}

Precursors of the fragments $m / z 348$ and $m / z 362$ were scanned in the positive ion mode from $\mathrm{m} / \mathrm{z} 400$ to 950 under the following conditions: curtain gas: 10 psi, CAD: medium, ion spray voltage: $5500 \mathrm{~V}$, temperature: ambient, nebulizer gas: 10 psi, auxiliary gas: off, interface heater: on, declustering potential: $100 \mathrm{~V}$, entrance potential: $10 \mathrm{~V}$, collision energy: $70 \mathrm{~V}$, exit potential: $12 \mathrm{~V}$.

\subsubsection{Product ion spectra}

Product ion spectra were recorded in the Enhanced Product Ion (EPI) mode in the mass range from $\mathrm{m} / z 150$ to 930. Positive ionization and unit resolution mode were used. The following parameters were applied: curtain gas: $10 \mathrm{psi}$, CAD: medium, ion

Table 2

Mass transitions $m / z\left(Q_{1}>Q_{3}\right.$ mass $)$ and their respective AZAs.

\begin{tabular}{|c|c|c|}
\hline Mass transition & AZA & $\begin{array}{l}\text { Collision energy } \\
\text { (CE) }[\mathrm{V}]\end{array}$ \\
\hline $716>698$ & AZA-33 & 40 \\
\hline $816>798$ & AZA-34, AZA-39 & 40 \\
\hline $816>348$ & AZA-39 & 70 \\
\hline $828>810$ & AZA-3 & 40 \\
\hline $828>658$ & AZA-3 & 70 \\
\hline $830>812$ & AZA-35, AZA-38 & 40 \\
\hline $830>348$ & AZA-38 & 70 \\
\hline $842>824$ & AZA-1, AZA-6, AZA-40 & 40 \\
\hline $842>672$ & AZA-1 & 70 \\
\hline $842>348$ & AZA-40 & 70 \\
\hline $844>826$ & AZA-4, AZA-5 & 40 \\
\hline $846>828$ & AZA-37 & 40 \\
\hline $846>348$ & AZA-37 & 70 \\
\hline $854>846$ & AZA-41 & 40 \\
\hline $854>670$ & AZA-41 & 70 \\
\hline $856>838$ & AZA-2 & 40 \\
\hline $856>672$ & AZA-2 & 70 \\
\hline $858>840$ & AZA-7, AZA-8, AZA-9, AZA-10, AZA-36 & 40 \\
\hline $858>348$ & AZA-36 & 70 \\
\hline $860>842$ & Undescribed & 40 \\
\hline $872>854$ & AZA-11, AZA-12 & 40 \\
\hline $920>840$ & Compound B in Gu et al. (2013) & 40 \\
\hline $920>348$ & Compound B in Gu et al. (2013) & 70 \\
\hline $928>910$ & Compound C in Gu et al. (2013) & 40 \\
\hline $928>348$ & Compound C in Gu et al. (2013) & 70 \\
\hline
\end{tabular}

spray voltage: $5500 \mathrm{~V}$, temperature: ambient, nebulizer gas: $10 \mathrm{psi}$, auxiliary gas: off, interface heater: on, declustering potential: $100 \mathrm{~V}$, collision energy spread: $0,10 \mathrm{~V}$, collision energy: $70 \mathrm{~V}$.

\subsubsection{FT-ICR-MS measurements}

High resolution mass spectra were acquired with a solarix XR Fourier transform ion cyclotron resonance mass spectrometer (FTICR-MS; Bruker Daltonik GmbH, Bremen, Germany) equipped with a $12 \mathrm{~T}$ refrigerated actively shielded superconducting magnet (Bruker Biospin, Wissembourg, France), a dual ion source and Paracell analyzer cell (Nikolaev et al., 2011). The samples were ionized by electrospray ionization in positive ion mode (Bruker Daltonik GmbH, Bremen, Germany). Sample solutions were continuously infused using a syringe at a flow rate of $2 \mu \mathrm{L} \mathrm{min}{ }^{-1}$. 1. The detection mass range was set to $m / z 150-3000$. Ion accumulation time for each scan was set to $0.1 \mathrm{~s}$. Several scans were added for the final mass spectrum. Data sets were acquired with $4 \mathrm{MW}$ data points resulting in a resolving power of 450,000 at $\mathrm{m} / \mathrm{z} 400$. Spectra were zero-filled to process size of $8 \mathrm{M}$ data points before sine apodization.

Mass spectra were calibrated with arginine clusters using a linear calibration. A $10 \mu \mathrm{g} \mathrm{mL}^{-1}$ solution of arginine in $50 \%$ methanol was used to generate the clusters. Ion accumulation time was set to several seconds for MS/MS experiments for improved $\mathrm{S} / \mathrm{N}$ of the fragment mass peaks. The quadrupole isolation window was set to $0.5 \mathrm{Da}$ and collision energy was set to $30 \mathrm{eV}$.

\section{Results}

\subsection{Molecular characterization}

Ten strains of A. poporum from the Yellow Sea, East China Sea and South China Sea share identical ITS sequences with that of strain G25 (GenBank number: KC286572) and thus belong to ribotype $\mathrm{B}$, and the rest six strains share identical ITS sequences with that of strain G42 (GenBank number: KC286581) (Table 1) and thus belong to ribotype C (Gu et al., 2013). They differ from each other at 11 positions (98.3\% similarity).

\subsection{Toxin profiles}

Out of the 16 A. poporum strains tested, three strains (AZDH51, AZCH01, AZLY02) proved not to contain any known AZAs at a limit of detection of $3-6$ ag cell $^{-1}$ (depending on the available cell biomass) expressed as AZA-1 equivalents. In addition, all strains were analyzed in the precursor ion mode of $m / z 348$ and $m / z 362$ in order to detect unknown AZA variants, but no additional AZAs were found.

One strain (AZFC22) exclusively produced AZA-2 (Table 1, Fig. 1) at a cell quota of $4.4 \mathrm{fg} \mathrm{cell}^{-1}$. Two strains (AZBH01 and AZBH03) exclusively produced a new, yet undescribed azaspiracid with a molecular mass of $841 \mathrm{Da}$, named here AZA-40 at cell quotas of 0.9 and $0.5 \mathrm{fg} \mathrm{cell}^{-1}$, respectively. AZA-40 is a structural isomer of AZA-1, but in contrast to AZA-1, it belongs to the 348-type AZAs (Fig. 2) as AZA-36, $-37,-38$, and -39 , which have been shown before to be produced by A. poporum and A. languida (Krock et al., 2012). The sum formula of AZA- 40 was determined as $\mathrm{C}_{47} \mathrm{H}_{72} \mathrm{NO}_{12}$ by high resolution mass spectrometry (HRMS) (Table 3 ).

Three strains (AZDH43, AZDH55 and AZDH41) only produced AZA-11 at cell quotas of $0.8,1.6$ and $3.0 \mathrm{fg}^{\text {cell }}{ }^{-1}$ (expressed as AZA1 equivalents), respectively. The identity of AZA-11 was confirmed by comparison of retention times (not shown) and the CID spectra of a solution containing AZA-11 and the isobaric compound of $A$. poporum (Fig. 3). 


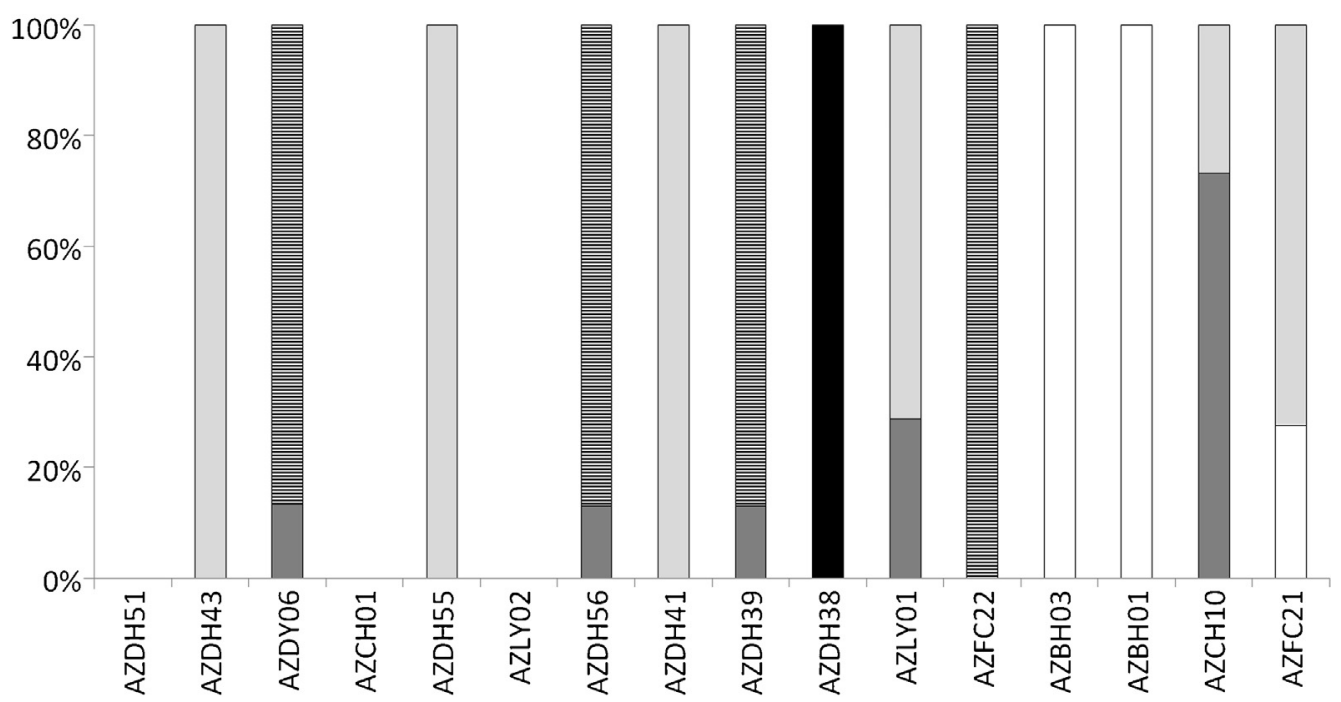

Fig. 1. Relative AZA-profiles of the Chinese A. poporum strains: AZA-41: black bars, AZA-40: white bars, AZA-36: dark grey bars, AZA-11: light grey bars, AZA-2: striped bars (—AZA-41 $\square$ AZA-40 $\square$ AZA-36 $\square$ AZA-11 目AZA-2).

Three strains (AZDY06, AZDH56 and AZDH39) produced AZA-2 and AZA-36. All three strains displayed a stable AZA-2/AZA-36 ratio, which consists of 6-6.5 times more AZA-2 (7.6, 1.8 and $3.9 \mathrm{fg} \mathrm{cell}^{-1}$ ) than AZA-36 (1.2, 0.3 and $0.6 \mathrm{fg}$ cell $^{-1}$, expressed as AZA-1 equivalents).

Strain AZDH38 produced another new AZA with a molecular mass of $853 \mathrm{Da}$ at a cell quota of $0.9 \mathrm{fg} \mathrm{cell}^{-1}$, here named AZA-41. AZA-41 belongs to a new group of AZAs, as all typical AZA group fragments of its collision induced dissociation (CID) spectrum are shifted to 2 Da lower $m / z$ values. The sum formula of AZA-41 was determined as $\mathrm{C}_{48} \mathrm{H}_{72} \mathrm{NO}_{12}$ by HRMS (Table 3).

Two strains (AZLY01 and AZCH10) produced AZA-11 (1.0 and $0.2 \mathrm{fg} \mathrm{cell}^{-1}$, respectively) and AZA-36 (0.4 and $0.7 \mathrm{fg} \mathrm{cell}^{-1}$, respectively) and strain AZFC21 produced AZA-11 and AZA-40 at cell quotas of 0.5 and $0.2 \mathrm{fg}_{\text {cell }}{ }^{-1}$, respectively. In summary, these 16 strains displayed eight different AZA profiles including the nontoxigenic variant.

In addition, some of the strains (AZCH10, AZDH39, AZDH56, AZDY06) produced minor amounts of an AZA variant with a molecular mass of 919 Da previously observed in this species (compound B in Gu et al., 2013). However, in none of the strains this compound exceeded $1 \%$ of the major AZA.

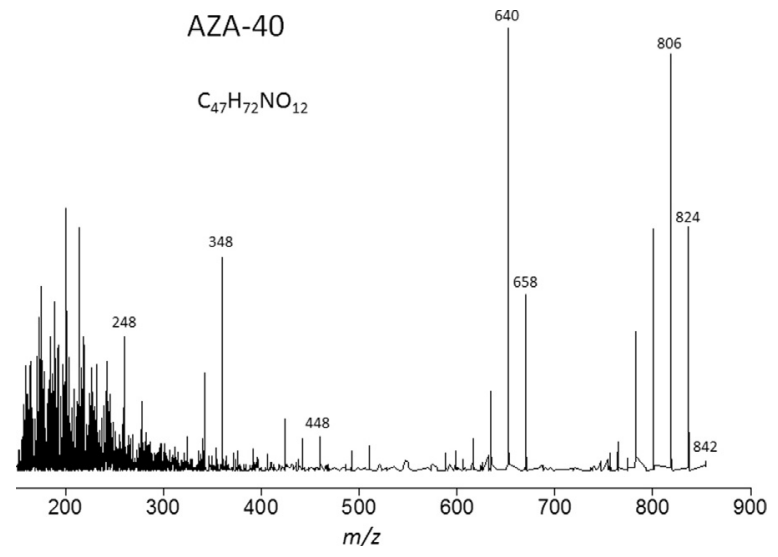

Fig. 2. Collision induced dissociation (CID) spectrum of AZA-40.

\section{Discussion}

\subsection{Toxin profiles}

Gu et al. (2013) reported three different AZA profiles out of six strains of $A$. poporum that previously had been isolated from Chinese coastal waters. This is noteworthy because it was first indication that variability of AZAs in this species seemed to be high compared to the closely related species $A$. spinosum, which to date among all four available strains displayed a unique AZA profile

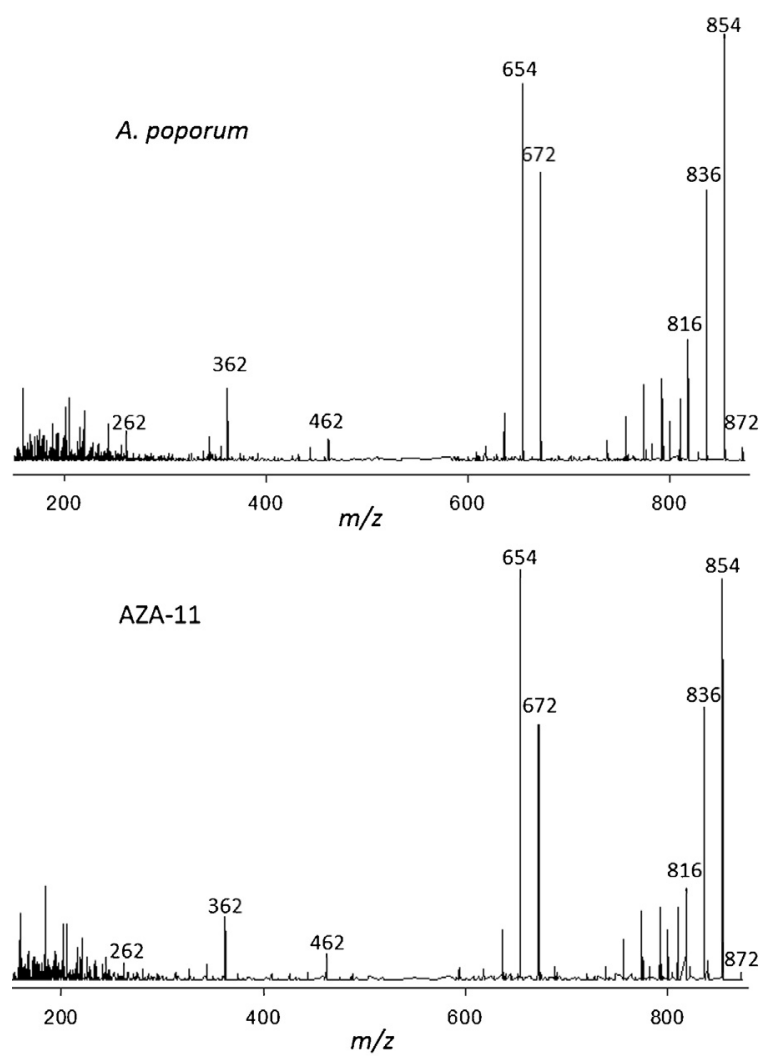

Fig. 3. Collision induced dissociation (CID) spectra of compound 871 Da of $A$. poporum (top) and AZA-11 (bottom). 
Table 3

exact masses of AZA-1, AZA-40 and AZA-41 and their characteristic fragments.

\begin{tabular}{|c|c|c|c|c|c|c|c|c|}
\hline & \multicolumn{2}{|c|}{ AZA-1 } & \multicolumn{3}{|l|}{ AZA-40 } & \multicolumn{3}{|l|}{ AZA-41 } \\
\hline & $m / z$ & Composition & Observed & Composition & $\pm \mathrm{ppm}$ & Observed & Composition & $\pm \mathrm{ppm}$ \\
\hline Group 1 & 842 & $\mathrm{C}_{47} \mathrm{H}_{72} \mathrm{NO}_{12}$ & 842,5049 & $\mathrm{C}_{47} \mathrm{H}_{72} \mathrm{NO}_{12}$ & 0.0 & 854,5050 & $\mathrm{C}_{48} \mathrm{H}_{72} \mathrm{NO}_{12}$ & 0.2 \\
\hline Group 2 & 672 & $\mathrm{C}_{38} \mathrm{H}_{58} \mathrm{NO}_{9}$ & 658,3950 & $\mathrm{C}_{37} \mathrm{H}_{56} \mathrm{NO}_{9}$ & 0.0 & 670,4262 & $\mathrm{C}_{38} \mathrm{H}_{56} \mathrm{NO}_{9}$ & 0.0 \\
\hline Group 3 & 462 & $\mathrm{C}_{27} \mathrm{H}_{44} \mathrm{NO}_{5}$ & 448,3057 & $\mathrm{C}_{26} \mathrm{H}_{42} \mathrm{NO}_{5}$ & 0.1 & 460,3057 & $\mathrm{C}_{27} \mathrm{H}_{42} \mathrm{NO}_{5}$ & 0.0 \\
\hline Group 4 & 362 & $\mathrm{C}_{22} \mathrm{H}_{36} \mathrm{NO}_{3}$ & 348,2533 & $\mathrm{C}_{21} \mathrm{H}_{34} \mathrm{NO}_{3}$ & 0.1 & 360,2533 & $\mathrm{C}_{22} \mathrm{H}_{34} \mathrm{NO}_{3}$ & 0.1 \\
\hline Group 5 & 262 & $\mathrm{C}_{16} \mathrm{H}_{24} \mathrm{NO}_{2}$ & 248,1645 & $\mathrm{C}_{15} \mathrm{H}_{22} \mathrm{NO}_{2}$ & 0.0 & 260,1645 & $\mathrm{C}_{16} \mathrm{H}_{22} \mathrm{NO}_{2}$ & 0.1 \\
\hline Group 6 & 168 & $\mathrm{C}_{10} \mathrm{H}_{18} \mathrm{NO}$ & 154,1227 & $\mathrm{C}_{9} \mathrm{H}_{16} \mathrm{NO}$ & 0.2 & 166,1227 & $\mathrm{C}_{10} \mathrm{H}_{16} \mathrm{NO}$ & 0.3 \\
\hline
\end{tabular}

consisting only of AZA-1, -2 and AZA-33 (AZA with molecular mass of 715 Da,Tillmann et al., 2012; Kilcoyne, pers. comm.). With respect to toxin profile in $A$. poporum, strains from the North Sea produced AZA-37 (compound 2 in Krock et al., 2012), A. poporum from the west coast of Korea produced AZA-36 (compound 1 in Krock et al. (2012)), and, as mentioned before, six strains of $A$. poporum from Chinese coastal waters (Gu et al., 2013) produced AZA-2, AZA-36 (compound 1) and an AZA with a molecular mass of $871 \mathrm{Da}$ (compound A in Gu et al., 2013), which we now identified as AZA-11 (Table 4). Both, retention times (data not shown) and CID spectra of AZA-11 and the compound with the molecular mass of $871 \mathrm{Da}$ in $A$. poporum are identical (Fig. 3). Although this structure has already been proposed based on mass spectral interpretation, the unambiguous identification as AZA-11 was still pending.

The occurrence of AZA-11 is particularly interesting, because until now it has only been regarded as a shellfish metabolite of AZA-2, which is formed by enzymatic hydroxylation in bivalves (James et al., 2003). Here we clearly show that AZA-11, apart from being shellfish metabolite, also is de novo synthesized by at least one species of dinoflagellates.

Among the 16 strains of $A$. poporum investigated in this work, we found eight different profiles with different combinations of the already observed AZAs, but also new ones.

\section{2. $A Z A-40$}

Three strains (AZBH01, AZBH03 and AZFC21) gave a peak in the SRM measurements in the ion transition for AZA-1 m/z $842>824$ almost at the retention time of AZA-1. However, the qualifying transition $m / z 842>672$ was missing, questioning the identity of AZA-1. For this reason we recorded a CID spectrum of this compound and in fact it turned out not to be AZA-1, but an isomer of AZA-1 belonging to the 348-type, which previously has been described in strains of Azadinium poporum and Amphidoma languida. The 348-type AZAs have a methyl (or methylene) group less in the part of the molecule consisting of C33-C39 (rings H, I) in comparison to the classical 362-type AZAs. This is also confirmed by HRMS, as the exact masses of the AZA group fragments match the theoretical values (Table 3 ). Even though the chemical structure of AZA-40 cannot be assigned by mass spectrometry alone but needs confirmation by nuclear magnetic resonance (NMR) spectroscopy, this finding is important in order to avoid misinterpretation of AZA-1 in the presence of AZA-40. Both

Table 4

Retention times (for method details see Section 2.3.1) and pseudo molecular ions $\left([\mathrm{M}+\mathrm{H}]^{+}\right]$of AZAs present in the Chinese strains of A. poporum and AZA-1.

\begin{tabular}{lll}
\hline Azaspiracid & Retention time $[\mathrm{min}]$ & $\mathrm{m} / \mathrm{z}\left([\mathrm{M}+\mathrm{H}]^{+}\right)$ \\
\hline AZA-36 & 10.84 & 858 \\
AZA-11 & 11.13 & 872 \\
AZA-40 & 12.03 & 842 \\
AZA-1 & 12.09 & 842 \\
AZA-41 & 12.23 & 854 \\
AZA-2 & 12.48 & 856 \\
\hline
\end{tabular}

compounds have identical molecular masses and, in addition, almost identical retention times. Under our chromatographic conditions AZA-1 was eluting at 12.09 min and AZA-40 slightly earlier at $12.03 \mathrm{~min}$. This is especially critical, because AZA-1 is regulated in many countries including the European Union by food safety legislation, but AZA-40, as a new compound, obviously is not.

In 2010, Yao et al. (2010) reported the presence of AZA-1 in Chinese shellfish. The mode of detection they used included fast chromatography and only one ion trace. These conditions are not sufficient for the distinction of AZA-1 and AZA-40. Given the fact that to date there is no known producer of AZA- 1 in Chinese waters, but we could show the presence of AZA-40 by its progenitor $A$. poporum in this region, it may very well be the case that AZA-1 has been misidentified by Yao et al. However, more work is needed to fully understand the global geographic distribution of AZAs, but especially in the western Pacific region.

\section{3. $A Z A-41$}

Strain AZDH38 displayed a peak in the ion chromatograms of transitions $m / z 856>838$ and $m / z 856>672$, which are characteristic for AZA-2. However, this peak eluted at $12.23 \mathrm{~min}$, slightly before AZA-2 (Fig. 5), which eluted at $12.48 \mathrm{~min}$. A CID spectrum of $\mathrm{m} / \mathrm{z} 856$ showed the identical fragments as AZA-2, but all group fragments consisted of three subsequent nominal masses, for example, the group 2 fragment $\mathrm{m} / \mathrm{z} 672$ consisted of three subsequent mass peaks with $m / z$ 670, 671 and 672 (data not shown). This led to the conclusion that $\mathrm{m} / z 856$ might not be the pseudo-molecular ion of this compound, but of an ion with two ${ }^{13} \mathrm{C}$ atoms incorporated into a compound with a lower molecular mass. Accordingly, we recorded a CID spectrum with $m / z 854$ instead. The CID spectrum of $m / z 854$ in turn looked like a "true" AZA spectrum (Fig. 4) and it shows that all group fragment ions (down to group 6 fragment $m / z 168$ for 362-type AZAs) are shifted to 2 Da smaller masses (Table 3 ). HRMS revealed that these mass shifts correspond

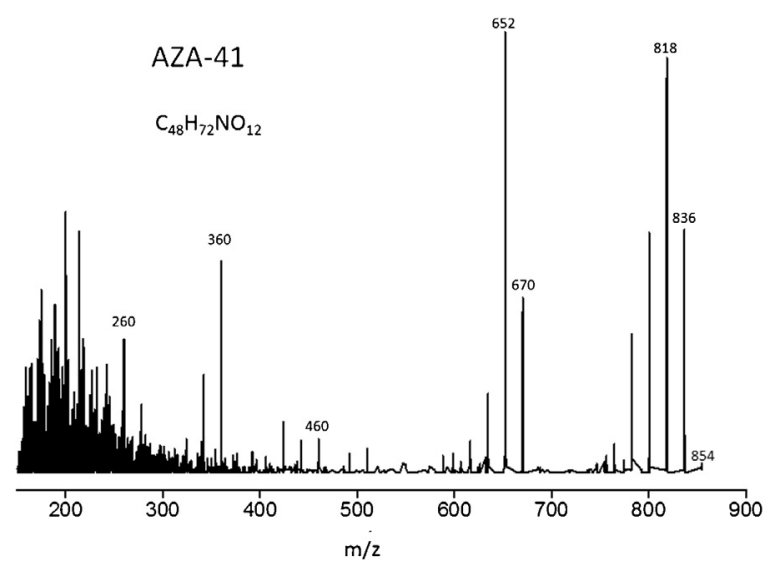

Fig. 4. CID spectrum of AZA-41. 


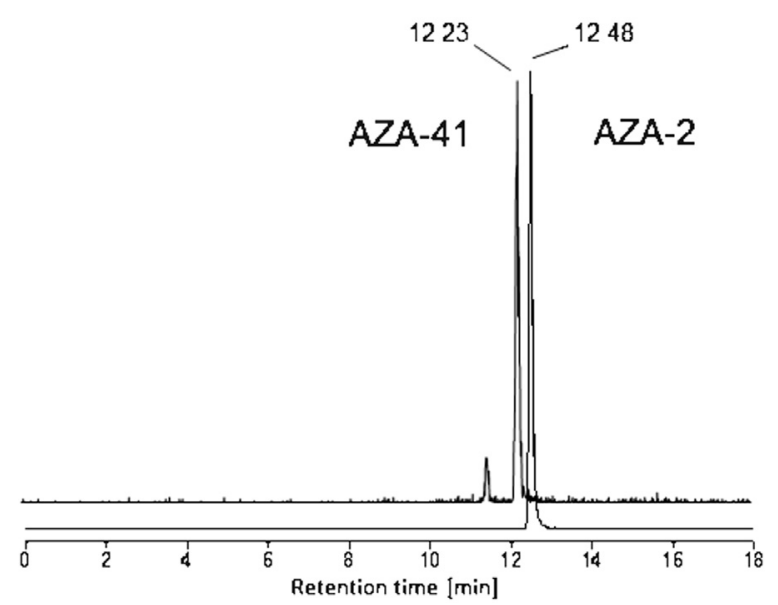

Fig. 5. LC-MS/MS selected ion chromatograms $(m / z \quad 856>838)$ of AZA-2 and AZA-41.

to sum formulas containing $2 \mathrm{H}$ atoms less than the corresponding 362-type fragments. This finding is a strong indication for a double bond in the part of the molecule consisting of C33-C39 (rings $\mathrm{H}, \mathrm{I}$ ) in comparison to the 362-type AZA-2. This means that besides the 348-type and 362-type, with AZA-41 there is third class, the 360type class. However, as in the case of AZA-40, the exact structure of AZA-41 needs to be elucidated by NMR spectroscopy and will be subject of future work.

As in the case of AZA-40, the occurrence of AZA-41 is noteworthy, because there is the potential of misidentifying
AZA-41 as AZA-2, due to the fact that both compounds elute in a narrow retention time window and give signals in the same MS/MS transitions, because of the naturally occurring stable carbon isotope ${ }^{13} \mathrm{C}$, even though both compounds differ in their molecular masses in two nominal mass units. AZA-41 with two ${ }^{13} \mathrm{C}$ incorporated has the same molecular ion and fragments as only ${ }^{12} \mathrm{C}$ containing AZA-2. Like in the case of AZA- 1 and AZA-40, also in the case of AZA-2 and AZA-41 there are two structurally different AZAs easy to be confused, but one is regulated by food safety legislation (AZA-2) and the other, obvious for a new compound, is not (AZA-41).

\subsection{Geographic distribution}

Combining the present data set with previously published data (Gu et al., 2013), we now have AZA-profiles of 22 strains of $A$. poporum from Chinese coastal waters (Table 1 ), which allow an evaluation of potential distribution pattern (Fig. 6). AZA-11 and AZA-36 were the most widely distributed AZAs. They occurred from the Bohai/Yellow Sea in the north, through the East China Sea to the South China Sea. AZA-2 was only detected in strains from the East China Sea and the South China Sea, whereas AZA-40 was only detected in two strains both from the South China Sea, and AZA-41 only in the East China Sea, albeit in just one strain. Strains without any AZAs were only found in the Yellow Sea and the East China Sea. In general, there seems to be no clear trend in the geographic distribution of neither the two ribotypes of $A$. poporum nor the different AZA variants in the different strains of $A$. poporum. Both ribotypes were found along the entire Chinese coastline such as AZA-11 and AZA-36. The seemingly more restricted occurrence of

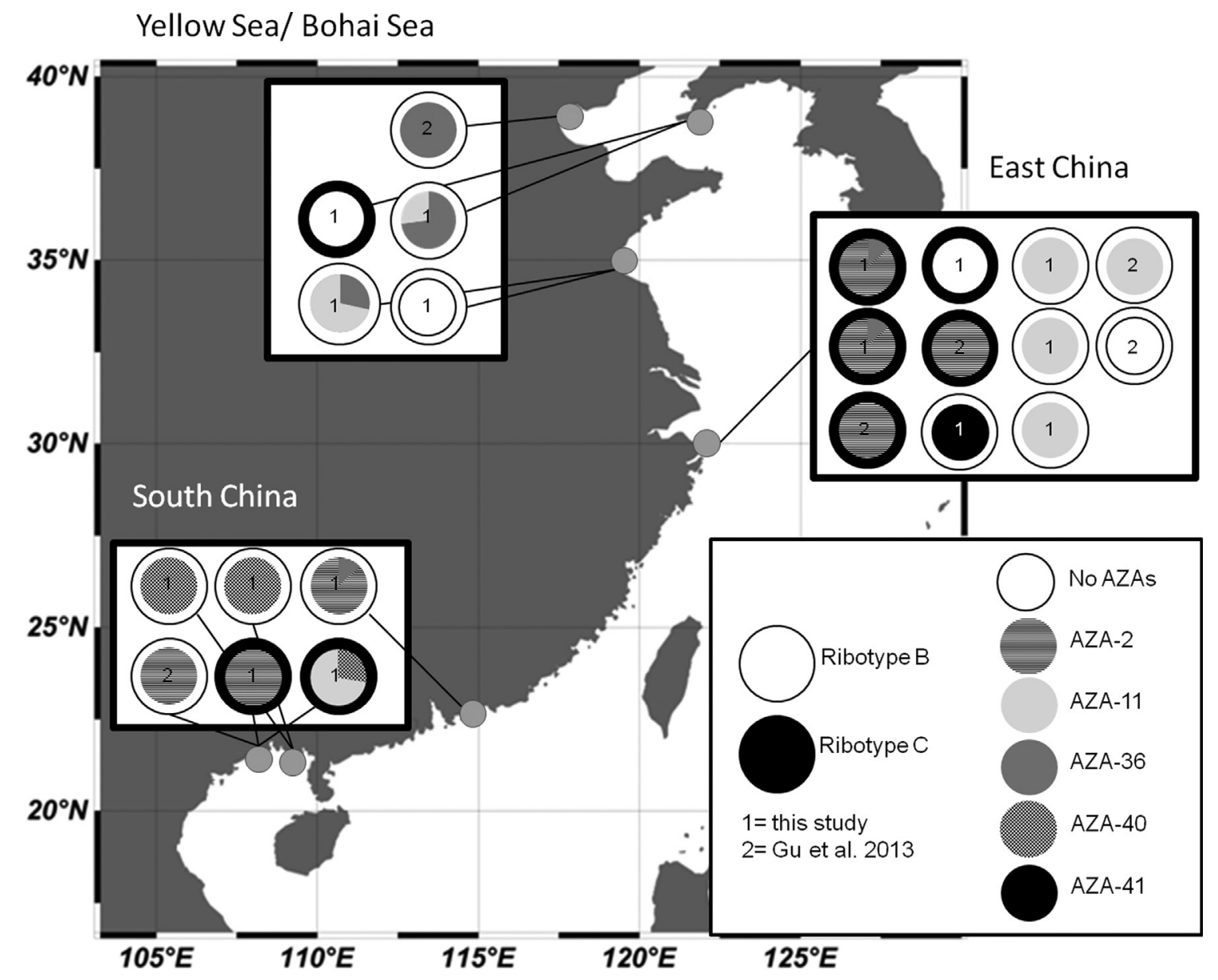

Fig. 6. Ribotypes, relative AZA profiles and geographic origin of the A. poporum strains used in this study. 
non-toxigenic strains, AZA-2, AZA-40 and AZA-41 along the Chinese coast might simply be due to the still limited number of isolates. In any case, the AZA profiles of the western Pacific isolates of $A$. poporum have an interesting feature: Whereas the other known AZA-producing strains of other species either exclusively produce 39-methyl-AZAs (362-type AZAs) as in the case of four strains of $A$. spinosum (Tillmann et al., 2012; Krock et al., 2013) or exclusively 39-desmethyl-AZAs (348-type AZAs) as in one strain of Amphidoma languida (Krock et al., 2012), both types, namely the 348-type AZAs AZA-36, AZA-40 and AZA-41 and the 362-type AZAs AZA-2 and AZA-11, which were found in A. poporum from the north western Pacific, were even simultaneously present in some isolates.

\section{Conclusions}

Whereas the first species identified as progenitor of AZAs and AZP, A. spinosum, seems to have a stable toxin profile consisting of AZA-1, -2 , and -33 , the more recently identified source organism for AZAs, A. poporum, displays a much higher variability of AZA profiles. Toxin profiles do not only differ among different geographic regions such as the North East Atlantic and the North West Pacific, but also among populations of the same geographic origin. In 16 isolates of $A$. poporum, we found 8 different AZA profiles including non-toxigenic strains without any AZAs. In addition we found two new AZAs, AZA-40 and AZA-41. AZA-40 is an isomer of AZA- 1 and having an almost identical retention time as AZA-1, it may be easily misidentified as AZA-1. Even though AZA-41 differs from AZA-2 in a 2 Da lower molecular mass, AZA-41 also can be easily misinterpreted as AZA-2, due to the significant proportion of the double ${ }^{13} \mathrm{C}$ signal. As AZA- 1 and -2 are regulated, but not AZA-40 and AZA-41, it is particularly important to distinguish between these two pairs of AZAs. For a full evaluation of potential risks of such a misidentification for shellfish consumers, toxicity data of the new compounds are needed.

\section{Acknowledgements}

We thank Jane Kilcoyne, Marine Institute, Oranmore, Galway, Ireland for the kind donation of an AZA-11 containing solution. Financial support was provided by the PACES research program of the AWI as part of the Helmholtz Foundation initiative in Earth and Environment. This study (Grant-Aid Agreement No. PBA/AF/08/ 001(01)) was partially carried out under the Sea Change strategy with the support of the Marine Institute and the Marine Research Sub-Programme of the National Development Plan 2007-2013, cofinanced under the European Regional Development Fund.[SS].

\section{References}

Adachi, M., Sako, Y., Ishida, Y., 1996. Cross-reactivity of fluorescent DNA probes to isolates of the genus Alexandrium by in situ hybridization. In: Yasumoto, T., Oshima, Y., Fukuyo, Y. (Eds.), Harmful and Toxic Algal Blooms. IOC-UNESCO, Paris, pp. 455-458.

Akselman, R., Negri, R.M., 2012. Blooms of Azadinium cf. spinosum Elbrächter et Tillmann (Dinophyceae) in northern shelf waters of Argentina, Southwestern Atlantic. Harmful Algae 19, 30-38.

Altschul, S.F., Madden, T.L., Schaffer, A.A., Zhang, J., Zhang, Z., Miller, W., Lipman, D.J., 1997. Gapped BLAST and PSI-BLAST: a new generation of protein database search programs. Nucleic Acids Res. 25, 3389-3402.
Braña Magdalena, A., Lehane, M., Krys, S., Fernández, M.L., Furey, A., James, K.J., 2003. The first identification of azaspiracids in shellfish from France and Spain. Toxicon 42, 105-108.

Gu, H., Luo, Z., Krock, B., Witt, M., Tillmann, U., 2013. Morphology, phylogeny and azaspiracid profile of Azadinium poporum (Dinophyceae) from the China Sea. Harmful Algae 21-22, 64-75.

Guillard, R.R.L., Ryther, J.H., 1962. Studies of marine planktonic diatoms, I. Cyclotella nana Hustedt and Detonula confervacea Cleve. Can. J. Microbiol. 8, 229-239.

James, K.J., Furey, A., Lehane, M., Ramstad, H., Aune, T., Hovgaard, P., Morris, S., Higman, W., Satake, M., Yasumoto, T., 2002. First evidence of an extensive northern European distribution of azaspiracid poisoning (AZP) toxins in shellfish. Toxicon 40, 909-915.

James, K.J., Sierra, M.D., Lehane, M., Braña Magdalena, A., Furey, A., 2003. Detection of five new hydroxyl analogues of azaspiracids in shellfish using multiple tandem mass spectrometry. Toxicon 41, 277-283.

Jauffrais, T., Herrenknecht, C., Séchet, V., Sibat, M., Tillmann, U., Krock, B., Kilcoyne, J., Miles, C.O., McCarron, P., Amzil, Z., et al., 2012. Quantitative analysis of azaspiracids in Azadinium spinosum cultures. Anal. Bioanal. Chem. 403, 833-846.

Klontz, K.C., Abraham, A., Plakas, S.M., Dickey, R.W., 2009. Mussel-associated azaspiracid intoxication in the United States. Ann. Internal Med. 150, 361.

Krock, B., Tillmann, U., John, U., Cembella, A.D., 2009. Characterization of azaspiracids in plankton size-fractions and isolation of an azaspiracid-producing dinoflagellate from the North Sea. Harmful Algae 8, 254-263.

Krock, B., Tillmann, U., Voß, D., Koch, B.P., Salas, R., Witt, M., Potvin, É., Jeong, H.J., 2012. New azaspiracids in Amphidomataceae (Dinophyceae). Toxicon 60, 830839.

Krock, B., Tillmann, U., Alpermann, T.J., Voß, D., Zielinski, O., Cembella, A.D., 2013. Phycotoxin composition and distribution in plankton fractions from the German Bight and western Danish coast. J. Plankton Res. 35, 1093-1108.

López-Rivera, A., O'Callaghan, K., Moriarty, M., O'Driscoll, D., Hamilton, B., Lehane, M., James, K.J., Furey, A., 2010. First evidence of azaspiracids (AZAs): A family of lipophilic polyether marine toxins in scallops (Argopecten purpuratus) and mussels (Mytilus chilensis) collected in two regions of Chile. Toxicon 55, 692-701.

McMahon, T., Silke, J., 1996. West coast of Ireland; winter toxicity of unknown aetiology in mussels. Harmful Algae News 14, 2.

Nézan, E., Tillmann, U., Bilien, G., Boulben, S., Chèze, K., Zentz, F., Salas, R., Chomerat, N., 2012. Taxonomic revision of the dinoflagellate Amphidoma caudata: transfer to the genus Azadinium (Dinophyceae) and proposal of two varieties based on morphological and molecular phylogenetic analyses. J. Phycol. 48, 925-939.

Nikolaev, E.N., Boldin, I.A., Jertz, R., Baykut, G., 2011. Initial experimental characterization of a new ultra-high resolution FTICR cell with dynamic harmonization. J. Am. Soc. Mass Spectrom. 22, 1125-1133.

Ofuji, K., Satake, M., McMahon, T., Silke, J., James, K.J., Naoki, H., Oshima, Y., Yasumoto, T., 1999. Two analogs of azaspiracid isolated from mussels, Mytilus edulis, involved in human intoxication in Ireland. Nat. Toxins 7, 99-102.

Percopo, I., Siano, R., Rossi, R., Soprano, V., Sarno, D., Zingone, A., 2013. A new potentially toxic Azadinium species (Dinophyceae) from the Mediterranean Sea, A. dexteroporum sp. nov. J. Phycol., http://dx.doi.org/10.1111/jpy.12104

Potvin, É., Jeong, H.J., Kang, N.S., Tillmann, U., Krock, B., 2012. First Report of the photosynthetic dinoflagellate genus Azadinium in the Pacific Ocean: morphology and molecular characterization of Azadinium cf. poporum. J. Eukaryotic Microbiol. 59, 145-156.

Salas, R., Tillmann, U., John, U., Kilcoyne, J., Burson, A., Cantwell, C., Hess, P., Jauffrais, T., Silke, J., 2011. The role of Azadinium spinosum (Dinophyceae) in the production of azaspiracid shellfish poisoning in mussels. Harmful Algae 10, 774-783.

Satake, M., Ofuji, K., Naoki, H., James, K.J., Furey, A., McMahon, T., Silke, J., Yasumoto, T., 1998. Azaspiracid, a new marine toxin having unique spiro ring assemblies, isolated from Irish mussels, Mytilus edulis. J. Am. Soc. Mass Spectrom. 120, 9967-9968.

Taleb, H., Vale, P., Amanhir, R., Benhadouch, A., Sagou, R., Chafik, A., 2006. First detection of azaspiracids in mussels in north west Africa. J. Shellfish Res. 25, 1067-1070.

Tillmann, U., Elbrächter, M., Krock, B., John, U., Cembella, A.D., 2009. Azadinium spinosum gen. et sp nov (Dinophyceae) identified as a primary producer of azaspiracid toxins. Eur. J. Phycol. 44, 63-79.

Tillmann, U., Elbrächter, M., John, U., Krock, B., Cembella, A.D., 2010. Azadinium obesum (Dinophyceae), a new nontoxic species in the genus that can produce azaspiracid toxins. Phycologia 49, 169-182.

Tillmann, U., Elbrächter, M., John, U., Krock, B., 2011. A new non-toxic species in the dinoflagellate genus Azadinium: A. poporum sp. nov. Eur. J. Phycol. 46, 74-87.

Tillmann, U., Soehner, S., Nézan, E., Krock, B., 2012. First record of the genus Azadinium (Dinophyceae) from the Shetland Islands, including the description of Azadinium polongum sp. nov. Harmful Algae 20, 142-155.

Yao, J., Tan, Z., Zhou, D., Guo, M., Xing, L., Yang, S., 2010. Determination of azaspiracid-1 in shellfish by liquid chromatography with tandem mass spectrometry. Chin. J. Chromatogr. 28, 363-367. 